\title{
CFD Analyses of Methods to Improve Air Quality and Efficiency of Air Cleaning in Pig Production
}

\author{
Bjarne Bjerg1, Guo-Qiang Zhang² and Peter Kai \\ 1 University of Copenhagen \\ ${ }^{2}$ University of Aarhus \\ Denmark
}

\section{Introduction}

Release of contaminant gaseous as ammonia, carbon dioxide, sulphur hydrogen, methane and laughing gas is an inevitable consequence of livestock production, and degrades air quality in the production facilities and has a negative impact on both the short and long distance environment. Generally the knowledge on how the content of these gases influence animal performance, animal health and the health's of the farmers is deficient, but it is commonly accepted that the concentrations of especially ammonia, hydrogen sulphide and carbon dioxide should be kept below certain thresholds (CIGR 1984). Ammonia is of special interest because the concentrations inside the housing system in some cases reach critical levels and because it, in large parts of the world, is assumed to be the livestock production gas that has the largest negative impact on the surrounding environment.

Ammonia in livestock housing originates from animal excretion of faeces and urine. Especially urine has a large content of urea which readily is transformed into ammonia upon contact with the enzyme urease:

$$
\begin{aligned}
& \text { urease } \\
& \left(\mathrm{NH}_{2}\right)_{2} \mathrm{CO}+\mathrm{H}_{2} \mathrm{O} \Rightarrow 2 \mathrm{NH}_{3}+\mathrm{CO}_{2}
\end{aligned}
$$

The required enzyme urease is present in faeces and therefore the generation of ammonium takes place when urine brings together with faeces. Successively a part of the generated ammonia will be transformed into ammonium in the solution:

$$
\mathrm{NH}_{3}+\mathrm{H}_{2} \mathrm{O} \Leftrightarrow \mathrm{NH}_{4}^{+}+\mathrm{OH}^{-}
$$

The lower $\mathrm{pH}$-value in the solution the larger part of the ammonia will be transformed to ammonium and that part is bound in the solution. The remaining ammonia will evaporate to the air above with a velocity that depends on numerous properties in the solution and in the air above.

Due to the negative influence of ammonia on air quality in the housing system and on the surrounding environment it is of large interests to design housing systems that limit the 
evaporation of ammonia or enable efficient removal of the evaporated ammonia to maintain low concentration in the room and low emissions to the surrounding.

The purpose of the work presented in this chapter is to demonstrate the possibilities to design ventilation systems that reduce the ammonia concentration in pig housing and simultaneously reduce the required ventilation capacity. In addition it is demonstrated how improved ventilation system design including strategically located exhausts can be utilised to capture a large part of released ammonia in a relative small share of the entire air change, and how cleaning of that minor part of the total air change may contribute to a significant reduction of the total ammonia emission.

The analyses discussed in this work are based on Computational Fluid Dynamics (CFD) which is a branch of modelling tools that use numerical methods and algorithms to analyse problems that involve fluid flow. A general overview of the CFD methods used in relation to ventilated rooms or more specifically related to the agricultural industry lies beyond the scope of this chapter but can beneficially be found in Nielsen et al. (2007) and Norton et al. (2007). In this chapter it is prioritised to give an in depth description of the necessary or preferred methods to solve the challenges related to the special issues treated in this work.

The use of CFD methods involves a geometrical description and delimitation of the fluid volume - often called the domain - that has to be included in order to analyse the required flow phenomena. In pig production it is conmen to use mechanical ventilations system were the outdoor wind conditions have a relatively small influence on the indoor airflow, and therefore it is reasonable to delimitate the analysed spaces to indoor air volume.

In Denmark and a few other European countries it is common to equip pig housings with mechanical under pressure ventilations system with air intake through porous material in the ceiling. Typically these inlets consist of a layer of mineral wool between timber beams with a cement bonded wood wool plate beneath, see Fig. 1.

In such a system, the air is entering the room with a velocity as low as 0.005 to $0.05 \mathrm{~m} / \mathrm{s}$, and, consequently, draft will seldom be a problem if the system is designed in accordance

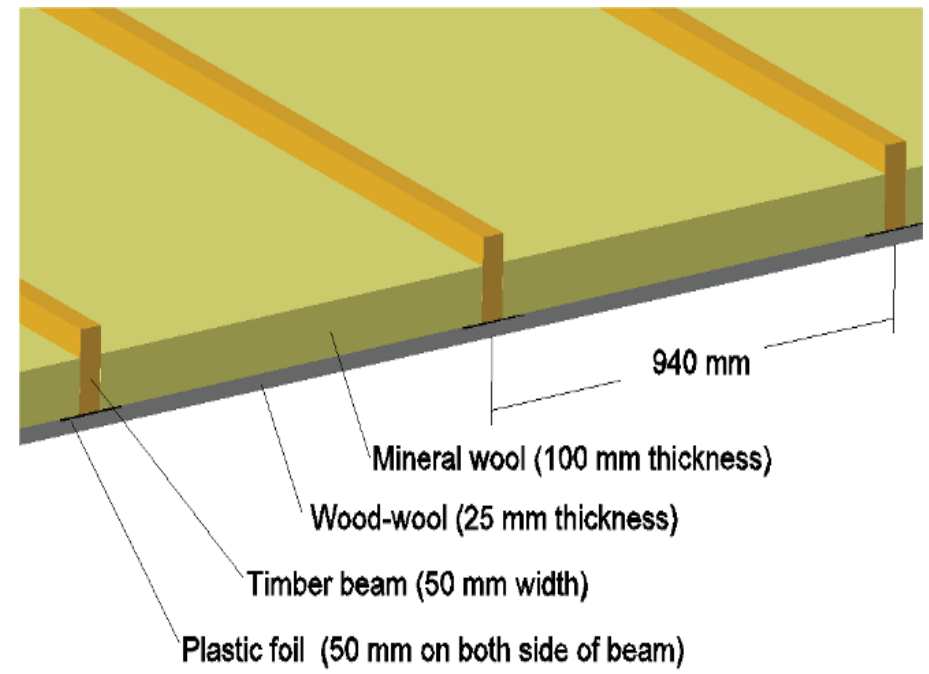

Fig. 1. Typical construction for diffuse air inlet through ceiling. 
with the existence empirical knowledge. However, the empirical knowledge is not sufficient to optimize room layout in order to improve air distribution in the animal occupied zone or in order to reduce the release of ammonia and odorants from manure. CFD (Computational Fluid Dynamics) is an obvious tool for such tasks, but until now, the reported experience of using CFD in relation to air intake through porous material in the ceiling is limited.

CFD modeling requires detailed geometrical description of the flow domain and division of the domain into a comprehensive grid. The procedure is very time consuming if it is used in complex setups with pen partitions, equipment, slatted floor and animals. Wu \& Gebremedhin (2001) performed CFD simulation of airflow around up to ten geometrically precise models of standing $600 \mathrm{~kg}$ Holstein cows. However, to simulate airflow in an animal room under operation, this method has the disadvantages that it is very time consuming to build such models, and that the animals are moving around and place themselves in different positions. A potential way to overcome this is to assume that the occupied zone consists of a porous media with a certain flow resistance. A similar method has been use to model airflow through slatted floor (Sun et al., 2004) and through partly open pen partitions (Wagenberg et al., 2004).

In this work the porous media assumption are utilized to avoid a detail geometrical modeling and complicated subdivision of the space around the animals the animals, and to model the condition in the porous inlet.

\section{Analyses of a partly pit ventilation system as method to reduces ammonia emission from a pig production unit}

To reduce ammonia and odour emission from livestock housing, the use of air cleaning systems is increasing. Available acid based exhaust air cleaning systems are capable of reducing ammonia emission through ventilation with approximately 95 percent (Melse \& Ogink 2005), but due to the large amount of air that must be treated the investment and operating costs are high. In many cases a reduction of ammonia emission of $30-70$ percent is sufficient to fulfil the requirement from legislation. Under northern Europe climate conditions the ventilation level is relatively low in a large part of the year resulting in high ammonia concentrations in exhaust air in those periods. This makes it possible to obtain a relatively large reduction of total ammonia emission with a cleaning system designed for a relatively small share of the total ventilation capacity.

The greater part of ammonia emission from pig production housing systems with slatted floor is released from the slurry surface. In this type of production units pit ventilation has been known as a method to improve indoor air quality, but it is seldom used due to increased energy cost and increased emission of ammonia and odour.

The scope of this work is to investigate the efficiency of a partly pit ventilation system with cleaning of the air exhausted from the pit. The investigation is based on theoretical calculations including CFD methods (Computational Fluid Dynamics) to predict airflow, and ammonia release and distribution in a growing pig unit.

\subsection{Methods}

The analyses were based on conditions in a typical Danish pig unit for growing pigs from 30 to $100 \mathrm{~kg}$. The assumed unit included two rows of $2.4 \mathrm{~m}$ wide and $4.8 \mathrm{~m}$ long pens designed for 16 pigs each, see Fig. 2 and 3. 

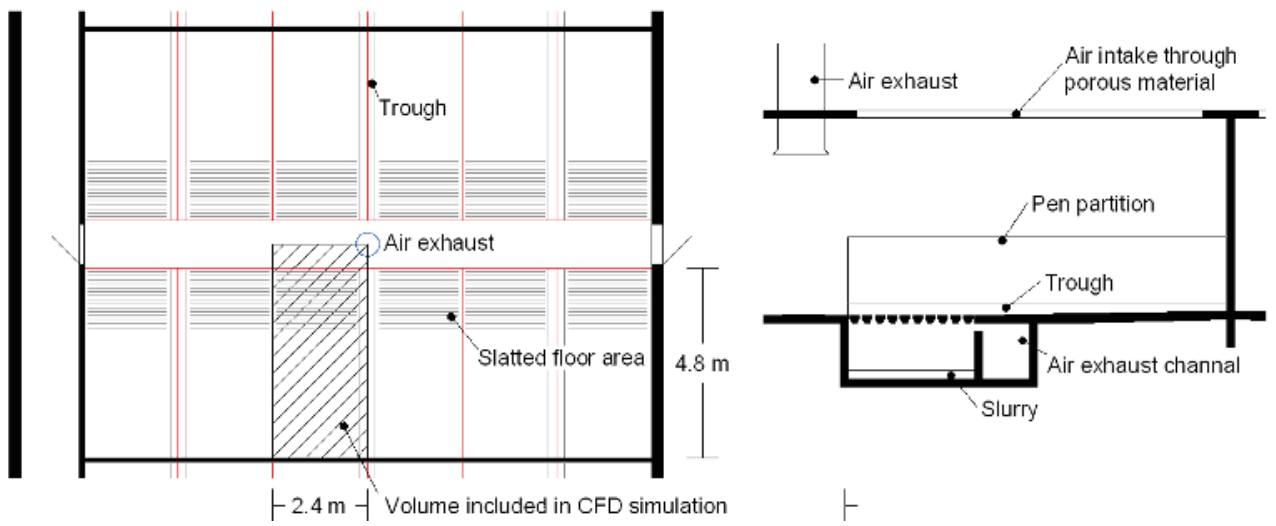

Fig. 2. Plan and cross section of assumed pig production unit.

One third of the pen area consists of slatted floor with a slurry pit beneath and the unit is equipped with negative pressure ventilation system with air intake through porous material in the ceiling. Along the slurry pit an assumed air exhaust channel makes it possible to evacuate a share of total exhaust air directly from pit, see Fig. 5. The maximum ventilation capacity was assumed to be $100 \mathrm{~m}^{3} \mathrm{~h}^{-1} \mathrm{pig}^{-1}$, and StaldVent 5.0@ software (Strom \& Morsing 2004) were used to calculated the distribution of expected ventilation levels during a year, see Fig. 4.

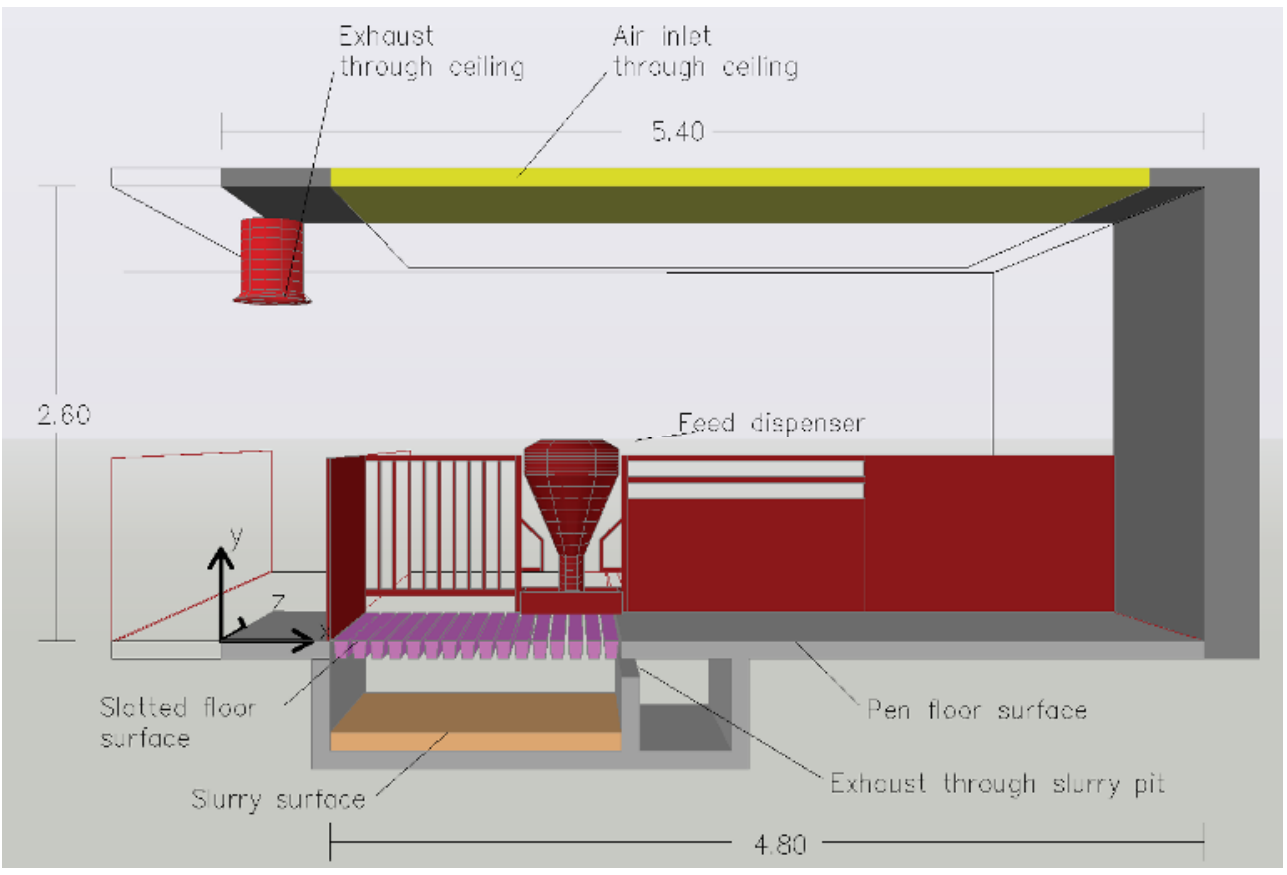

Fig. 3. Perspective and used system of coordinates in the assumed pig production unit. 


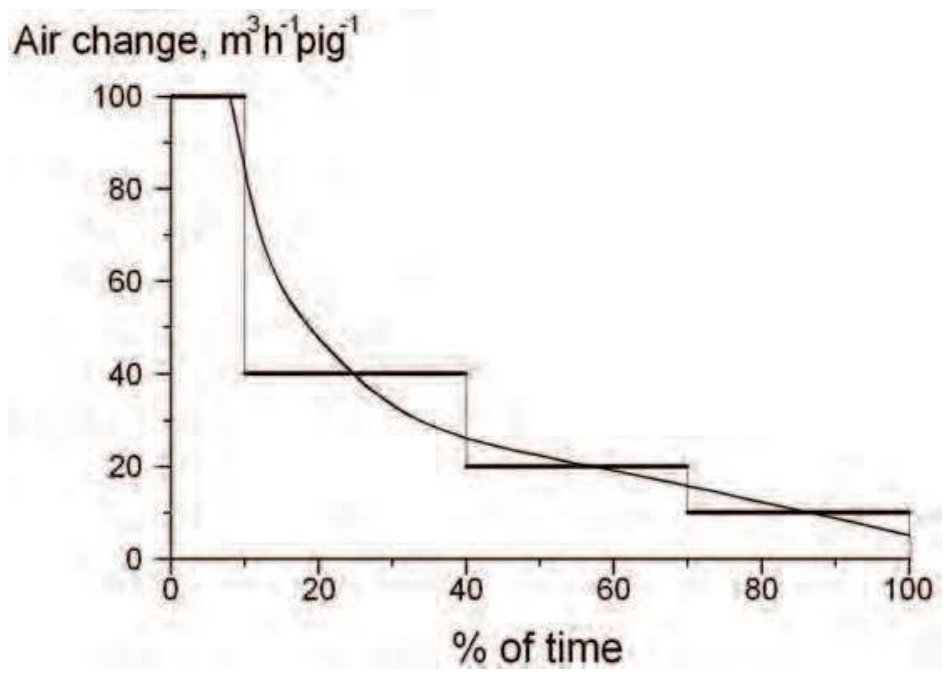

Fig. 4. Expected distribution of ventilation levels in a growing pig unit under Danish conditions (smooth curve), and four representative levels of ventilation (step curve) used in modelling of ammonia release and emission.

\subsubsection{CFD modelling}

The commercial CFD (Computational fluid Dynamic) code Fluent 6 (Anonymous 2006) were used to calculated air flow and ammonia distribution in one pen section of the room, see Fig. 2. The chosen section was divided into 37722 hexahedral cells and the grid on surfaces is shown in Fig. 5.

\subsubsection{Porous media assumptions}

Porous media boundary conditions were utilised to model airflow in three special regions of the used geometrical model:

- Porous material for air intake in the ceiling,

- Slatted floor partly covered with pigs, and

- Pigs in animal occupied zone pigs up to $0.6 \mathrm{~m}$ above floor level.

The flow resistance in each of the three directions $(x, y$ and $z)$ in the porous media regions were calculated using equation 1 (Bjerg et al., 2008; anonymous 2006).

$$
\Delta p=0.5 \cdot R_{1} \cdot \rho \cdot v^{2}+\mu \cdot R_{2} v
$$

where

$\Delta p \quad$ is pressure drop over the porous media, $\mathrm{Pa}$,

$R_{1}$ internal risistance factor,

$R_{2} \quad$ viscus risistance coefficient

$\rho$ air density, $\mathrm{kg} / \mathrm{m}^{3}\left(1.2 \mathrm{~kg} \mathrm{~m}^{-3}\right.$ at $\left.20^{\circ} \mathrm{C}\right)$

$v \quad$ air velocity, through porous media, $\mathrm{m} / \mathrm{s}$

$\mu \quad$ air viscosity, $\mathrm{kg} \mathrm{m}^{-1} \mathrm{~s}^{-1}\left(1.8 \cdot 10^{-5} \mathrm{~kg} \mathrm{~m}^{-1} \mathrm{~s}^{-1}\right.$ at $\left.20^{\circ} \mathrm{C}\right)$ 


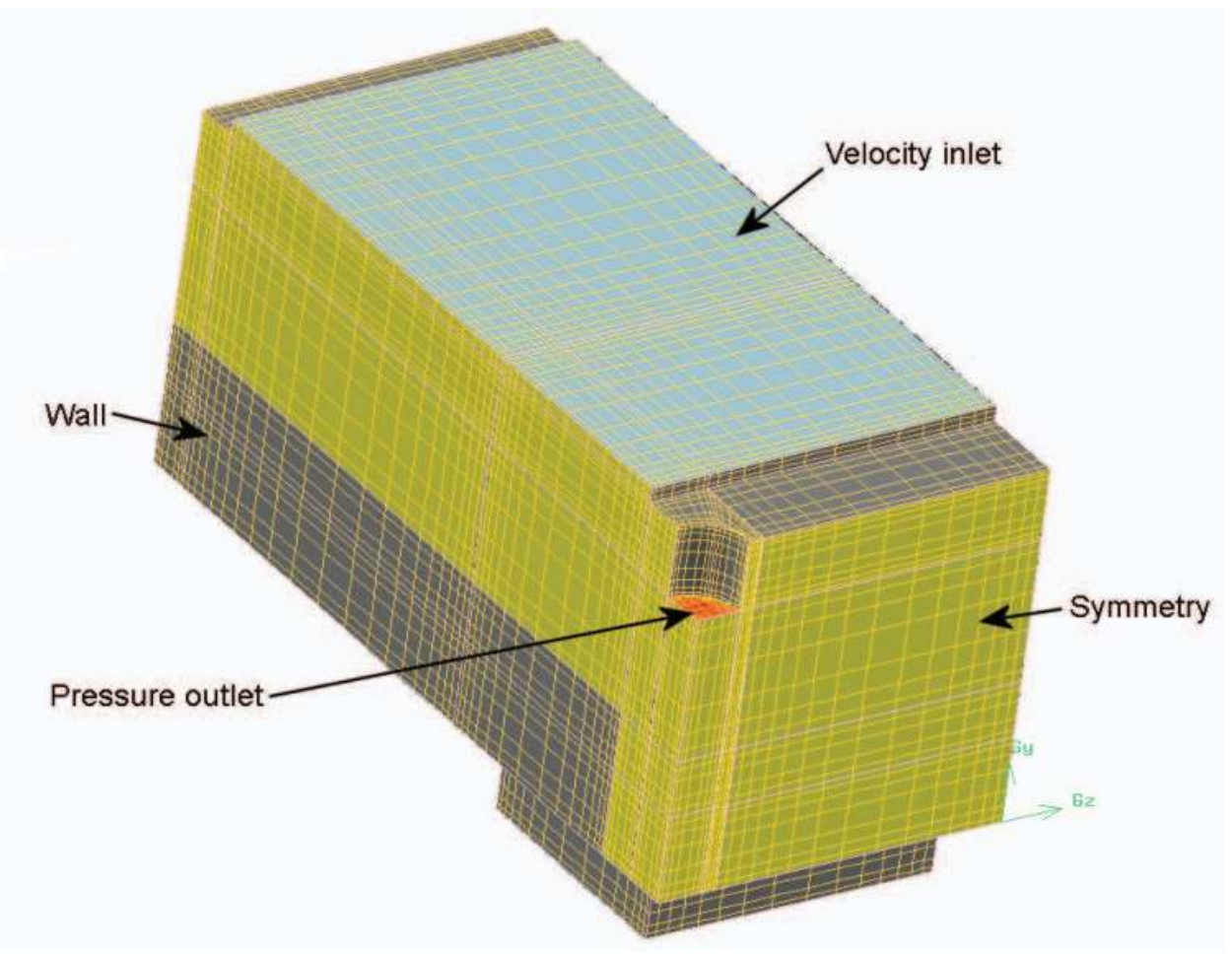

Fig. 5. Grid and boundary conditions on surfaces of the volume included in CFD modelling.

\subsubsection{Flow resistance properties for air inlet}

Internal resistance factor $\left(\mathrm{R}_{1}\right)$ and viscous resistance coefficient $\left(\mathrm{R}_{2}\right)$ through air inlet was determined from existing measurement of pressure drop through $100 \mathrm{~mm}$ mineral wool and $25 \mathrm{~mm}$ wood-wool (Anonymous, 1999). It appears from Fig. 1 that the plastic foil beneath the timber beams reduces the effective inlet area. But to avoid modelling each separate part of the inlet area in the subsequent CFD simulation the determined flow resistance parameters were adjusted to assure a realistic pressure drop if the inlet was modelled as a coherent area. Those adjusted flow resistance parameters appears from Table 1.

\subsubsection{Flow resistance properties for slatted floor}

Vertical flow resistance properties through slatted with and without assumed partly covering with pigs was determined in CFD simulation of airflow through detailed geometrical models of a segment of the floor, see Fig. 5 .

The resulting relation between inlet velocity and the pressure drop over the floors were used for determination of the values of $R_{1}$ and $R_{2}$ using equation 3 . The found values appear from Table 1. 


\begin{tabular}{lcccccr}
\hline & \multicolumn{2}{c}{ x-direction } & \multicolumn{2}{c}{ y-direction } & \multicolumn{2}{c}{ z-direction } \\
& $\mathrm{R}_{1}$ & $\mathrm{R}_{2}$ & $\mathrm{R}_{1}$ & $\mathrm{R}_{2}$ & $\mathrm{R}_{1}$ & $\mathrm{R}_{2}$ \\
\hline Porous ceiling $^{2}$ & 4000 & $5.4 \cdot 10^{6}$ & 4000 & $5.4 \cdot 10^{6}$ & 4000 & $5.4 \cdot 10^{6}$ \\
Slatted floor $^{3}$ & - & - & 40 & 11000 & 40 & 11000 \\
Slatted floor with pigs $^{3}$ & - & - & 80 & 15000 & 80 & 15000 \\
Drained floor $^{3}$ & - & - & 160 & 22000 & 160 & 22000 \\
Drained floor with pigs $^{3}$ & - & - & 4400 & 60000 & 4400 & 60000 \\
AOZ, activity area $^{4}$ & 0.4 & 400 & 0.4 & 400 & 0.4 & 400 \\
AOZ, resting area $^{4}$ & 1.3 & 1500 & 1.3 & 1500 & 1.3 & 1500 \\
& & & & & &
\end{tabular}

1System of coordinate orientation appears from Fig. 2.

${ }^{2}$ Resistance in horizontal directions assumed to be equal to resistance in vertical direction.

3Slats blocks for flow in $\mathrm{x}$-direction and resistance in $\mathrm{z}$-direction assumed to be equal to resistance in $\mathrm{y}$ direction.

${ }^{4}$ Resistance in vertical direction assumed to be equal to resistance in horizontal directions.

Table 1. Overview over used flow resistance properties.

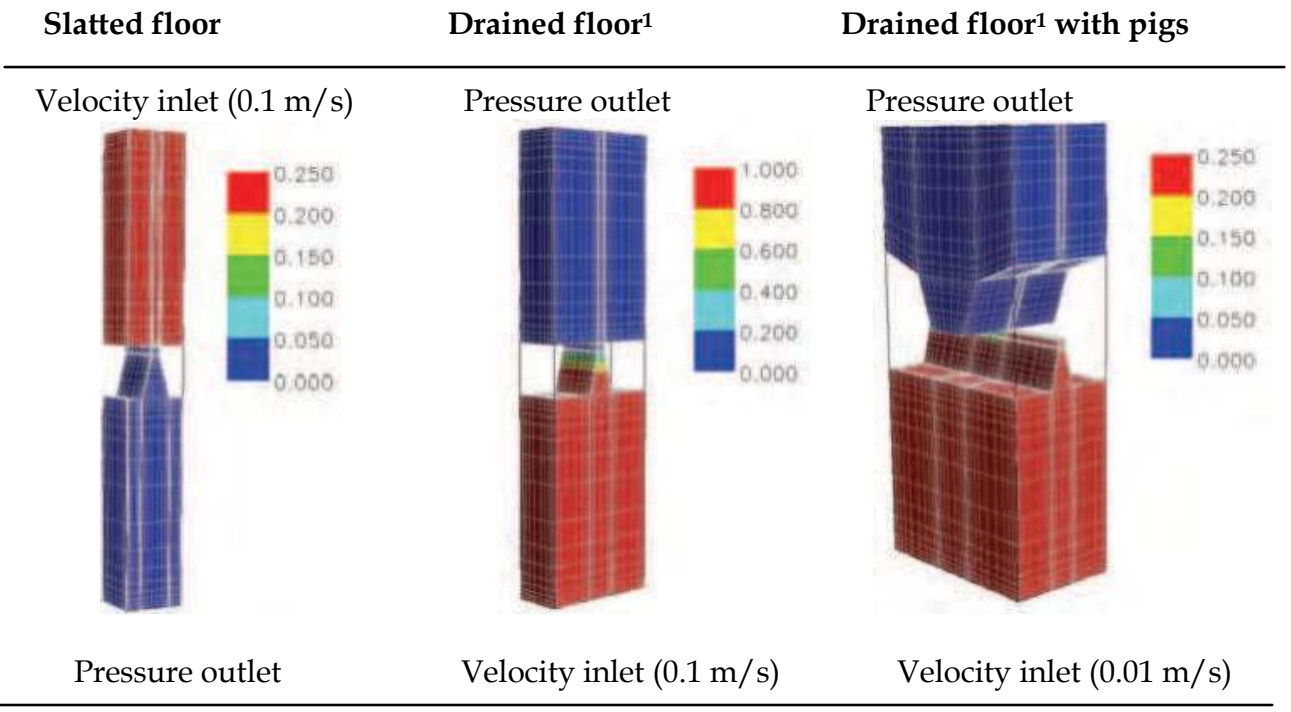

${ }^{1}$ Danish animal welfare legislation do not allow slatted floor with opening ratio of more than $10 \%$ in the animal resting area, and the phrase "drained floor" is used for floor with opening ratio below $10 \%$.

Fig. 6. Grid and pressure distribution (Pa) on surfaces of simulation models for determination of flow resistance through slatted floor drained floor and drained floor with pigs.

\subsubsection{Flow resistance properties for animal occupied zone.}

The presence of animals will restrict the air flow in the Animal Occupied Zone (AOZ). The defined height of the $\mathrm{AOZ}$ is related to the expected height of a standing pig. Height of 
standing pigs can be calculated as 0.16 (animal weight, $\mathrm{kg})^{0.33}, \mathrm{~m}$ (Baxter 1984). For growing finishing pigs from 30 to $100 \mathrm{~kg}$ this results in heights from 0.49 to $0.73 \mathrm{~m}$. In this work the determination of flow resistances is based on an assumed animal weight of $50 \mathrm{~kg}$ and a height of animal occupied zone of $0.6 \mathrm{~m}$. The AOZ is assumed to be divided into resting including the third of the pen in largest distance from the slatted floor and an activity area including the remaining two thirds of the pen area. Based on 16 pigs in the pen following distribution of animal on staying and laying positions in resting area and activity area was assumed:

8 pigs laying in resting area corresponding to $2.1 \mathrm{pigs} / \mathrm{m}^{2}$

1 pig standing in resting area corresponding to $0.26 \mathrm{pigs} / \mathrm{m}^{2}$

5 pigs laying in activity area corresponding to $0.65 \mathrm{pigs} / \mathrm{m}^{2}$

2 pigs standing in activity area corresponding to $0.26 \mathrm{pigs} / \mathrm{m}^{2}$

The flow resistance parameter for flow through the AOZ was determined in CFD simulation on geometrically fairly detailed models as shown in Fig. 7. The model illustrates assumed conditions in the resting area with the density of 2.1 laying pigs and 0.26 standing pigs per $\mathrm{m}^{2}$. The magnitude of the pigs corresponds to an average body weight of $50 \mathrm{~kg}$. The pigs are constructed as the intersection of two dimensional silhouettes from three different directions. Unstructured grid was used in simulation of airflow around the pigs. Air velocity boundary conditions were assumed at the left end face and pressure outlet conditions were assumed in the right end face of model in Fig. 7.

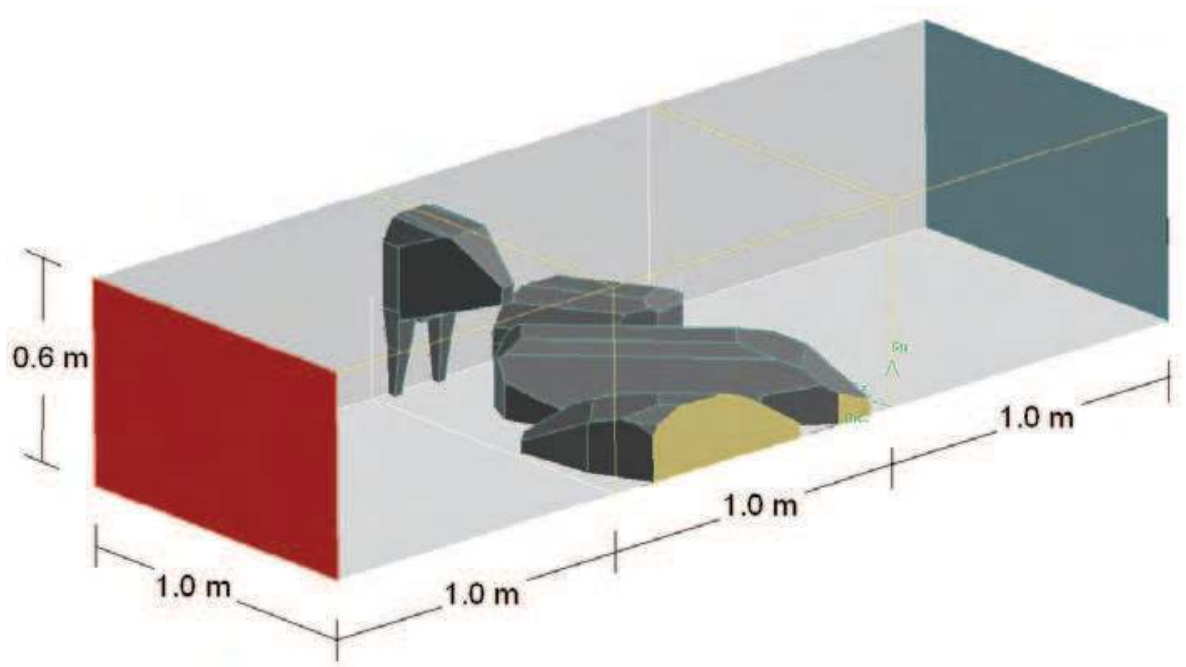

Fig. 7. Geometrical model used in simulation for determination of flow resistance through animal occupied zone with animal density of 2.1 laying and 0.26 standing $50 \mathrm{~kg}$ pig pr $\mathrm{m}^{2}$. Velocity inlet and pressure outlet boundary condition were assumed at the left and right face, respectively.

The resulting relation between inlet velocity and the pressure drop around the animals were used for determination of the values of $R_{1}$ and $R_{2}$ using Equation 3. The found values appear from Table 1. 


\subsubsection{Ventilation configurations}

Simulations were carried out with air intake of $10,20,40$ and $100 \mathrm{~m}^{3} \mathrm{~h}^{-1} \mathrm{Pig}^{-1}$ corresponding to inlet velocities of $0.00411,0.00822,0.01644$ and $0.0411 \mathrm{~m} / \mathrm{s}$, respectively. For each ventilation level simulations were carried out with $0,5,10$ and $20 \mathrm{~m}^{3} \mathrm{~h}^{-1} \mathrm{Pig}^{-1}$ air exhaust from the pit.

For room exhaust pressure outlet conditions were assumed on the entry to the ventilation shaft through the ceiling, see Fig. 5. For pit exhaust velocity outlet conditions were assumed on the entry surface on the connections between the slurry pit and the under floor exhaust channel, see Fig. 2 and 3. Fig. 5 illustrates that symmetry boundary conditions were assumed at the surface where the modelled section was cut out of the entire room.

\subsubsection{Ammonia release}

As ammonia source were assumed a constant concentration on slurry surface, and a level of $340 \mathrm{ppm}$ were chosen in order to obtain realistic ammonia concentrations in the room. Griskey (2002) state the diffusivity for ammonia in air at $295^{\circ} \mathrm{K}$ and $101325 \mathrm{~Pa}$ to $1.8 \times 10^{-}$ ${ }^{5} \mathrm{~m}^{2} \mathrm{~s}^{-1}$, and this value was utilized in the CFD calculations.

\subsubsection{Heat release}

Releasing of convective heat due to animal heat production in animal occupied zone was included in simulations as a heat source of $200 \mathrm{Wm}^{-3}$ in the volume from $0-0.6 \mathrm{~m}$ above the solid floor and of $100 \mathrm{Wm}^{-3}$ above the slatted floor, corresponding to a total heat supply of $54 \mathrm{~W}$ per pig. Radiation heat release from pigs and transmission heat loss from the building was not taken into account.

\subsubsection{Modeling of turbulence}

Compared to the widely used Standard k- $\varepsilon$ turbulence model (Launder \& Spalding, 1974) the realizable k- $\varepsilon$ turbulence model (Shih et al. 1995) has in earlier works (Bjerg et al., 2008) shown to be more suitable to handle turbulence in a room with air intake through porous material in the ceiling and, consequently, the realizable k- $\varepsilon$ turbulence model was used in this work.

\subsubsection{Calculation of ammonia emission}

In estimation of yearly average ammonia concentrations and emissions it was assumed that the ventilation system runs with 100 percent of its capacity in 10 percent of time and with 40, 20 and 10 percent of capacity in 30 percent of time each, see Fig 4.

Calculation of air cleaning efficiency was based on the assumption that the ammonia will be removed to a level of $1 \mathrm{ppm}$ in the treated air, which corresponds to the performance of commercial systems. A setup with treatment of all air from a unit without pit ventilation is used as reference case for estimating the efficiency of treating of pit exhaust or treating of a minor part of room (ceiling) exhaust.

\subsection{Results and discussion}

Fig. 8 shows simulated airflow and ammonia concentration distribution for the case with total ventilation of $40 \mathrm{~m}^{3} \mathrm{~h}^{-1} \mathrm{Pig}^{-1}$. The left picture show the case with a pit ventilation of 10 $\mathrm{m}^{3} \mathrm{~h}^{-1} \mathrm{Pig}^{-1}$, and the right picture show the case without pit ventilation.

It is clear that pit ventilation creates a significant reduction of ammonia concentration in the entire room. In the animal occupied zone ( 0 to $0.6 \mathrm{~m}$ above floor) the average concentration was reduced from 13.5 to $5.5 \mathrm{ppm}$ corresponding to a reduction of nearly 60 percent. 


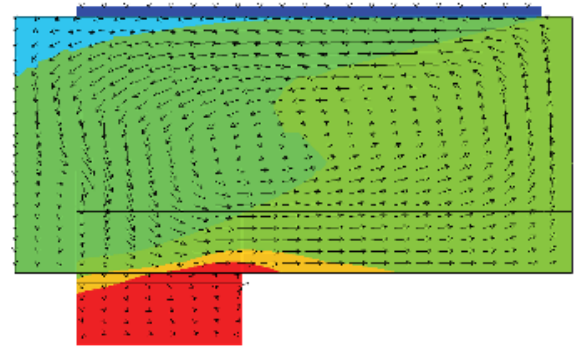

(a)

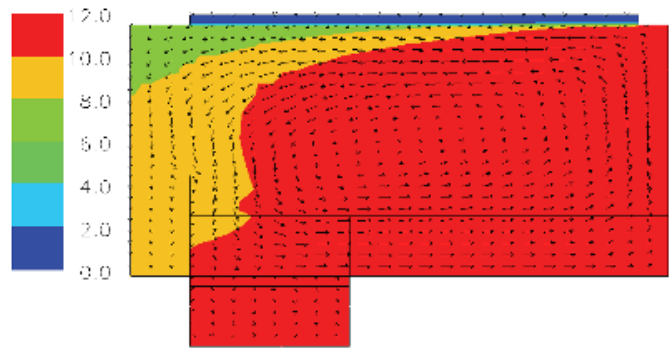

(b)

Fig. 8. Simulated airflow and ammonia distributions (ppm) at total ventilation of $40 \mathrm{~m}^{3} \mathrm{~h}^{-1} \mathrm{Pig}^{-1}$, (a) with pit ventilation of $10 \mathrm{~m}^{3} \mathrm{~h}^{-1} \mathrm{Pig}^{-1}$, and (b) without pit ventilation.

Fig. 9 shows ammonia concentration in the exhaust air from the room at different levels of air change from the pit and totally.

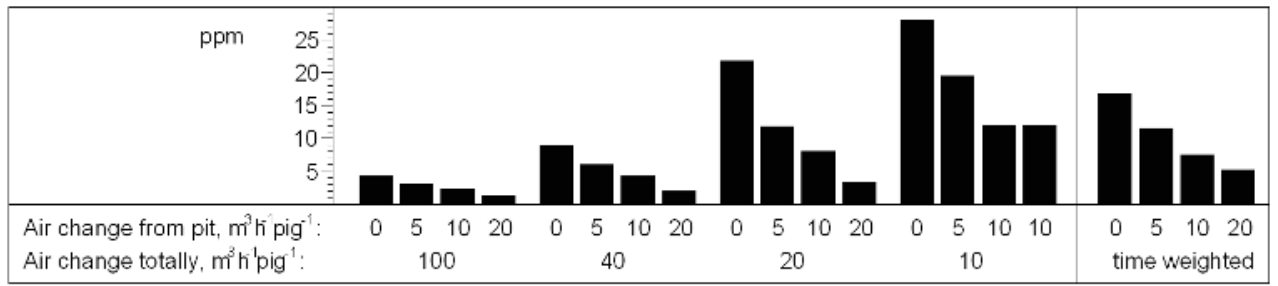

Fig. 9. Ammonia concentration in room exhaust at different pit ventilation and entire unit ventilation. Time weighted values, shown to the right in the graph, assumes total air change of $100 \mathrm{~m}^{3} \mathrm{~h}^{-1} \mathrm{Pig}^{-1}$ in 10 percent of time, and 40, 20 and $10 \mathrm{~m}^{3} \mathrm{~h}^{-1} \mathrm{Pig}^{-1}$ in 30 percent of time each.

As average during a year it is estimated that pit ventilation of 5, 10 and $20 \mathrm{~m}^{3} \mathrm{~h}^{-1} \mathrm{Pig}^{-1}$ will reduce ammonia concentration in the exhaust with 31, 55 and 68 percent, respectively, and inside the room the ammonia concentration will be reduced correspondently.

Fig. 10 shows total ammonia release and the emission from the room at different levels of air change from the pit and totally.

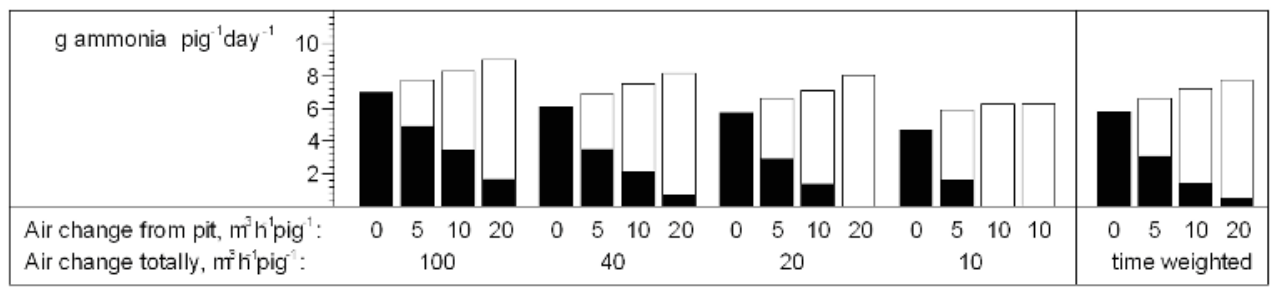

Fig. 10. Total ammonia release (aggregated bars) and emission from the room (black part of bars) at different levels of pit ventilation and entire unit ventilation. White part of bars show emission through pit exhaust assuming no air cleaning. 


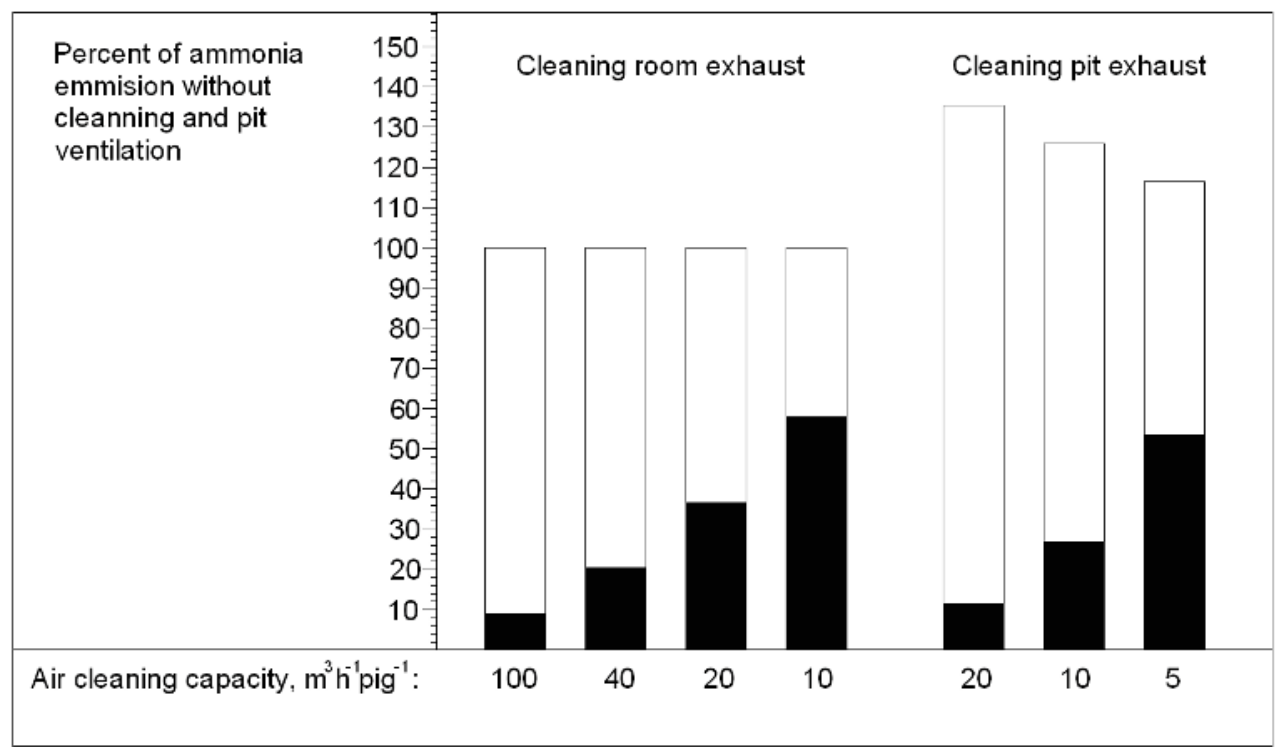

Fig. 11. Ammonia release (aggregated bars) and ammonia emission to the surroundings (black bars) at different air cleaning strategies. 100 percent corresponds to the ammonia emission from a unit with no air cleaning or pit ventilation. White part of bars shows removed ammonia.

It can be seen that an increased level of pit ventilation increased the ammonia release if cleaning system is not available. Using pit ventilations of 5, 10 and $20 \mathrm{~m}^{3} \mathrm{~h}^{-1} \mathrm{Pig}^{-1}$ during a year will result in increased ammonia emission of 16, 26 and 35 percent, respectively.

The simulation without pit ventilation showed that a decreased air change from 100 to 40 $\mathrm{m}^{3} \mathrm{~h}^{-1} \mathrm{Pig}^{-1}$ resulted in 13 percent decreased in ammonia emission. This can be compared with the result of a Danish investigation of the influence of air change on ammonia emission where the average air change were reduced from 80 to $40 \mathrm{~m}^{3} \mathrm{~h}^{-1} \mathrm{Pig}^{-1}$ (Lyngbye et al., 2006). In that investigation the room temperature was maintained by cooling the air inlet resulting in a reduction of the ammonia emission of 10 percent. The agreement with this investigation supports the assumption that a constant ammonia concentration on pit bottom surface is a reasonable simplification in CFD-modelling for analyzing the influence of ventilation strategy on ammonia emission.

Fig. 11 shows calculated performance of different cleaning strategies. For a unit with no pit ventilation it appears that cleaning of all exhaust air $\left(100 \mathrm{~m}^{3} \mathrm{~h}^{-1} \mathrm{Pig}-1\right)$ reduce ammonia emission with about 90 percent. If the cleaning system is designed to handle 10 percent of the ventilation capacity the reduction of ammonia emission is 41 percent, and measured in relation to the capacity of cleanings system this strategy is 4.5 times as efficient as cleaning all the air. Cleaning of 10 percent of the air exhausted directly from the pit removes 73 percent of the ammonia emission and related to the cleaning capacity this is 8 times as efficient as cleaning all the air from the room. But due to increased ammonia release in the pit ventilated system the consumption of acid to reduce the ammonia emission with a certain amount will increase with about 35 percent. 


\section{Airflow pattern and ventilation efficiency}

Ventilation systems in livestock buildings are designed to remove heat, moisture and containment gases in order to maintain temperatures and concentrations that are suitable for the animals. The airflow in pig units with diffuse air inlet through the ceiling is characterised by low air velocities primarily generated by the buoyancy force due to the convective heath release from the animals, and CFD-analyses have shown relative large spatial difference in temperature and concentrations in these systems, and consequently, there exists a potential to improve the ventilation effectiveness if the exhausts can be moved to locations with higher temperatures or concentrations.

Pigs are usually resting more than 80 percent of the time and the therefore the heat release will be most concentrated and generate a higher temperature and an upward air stream above the resting area. This has inspired to conduct an analysis of the influence of moving the exhaust to a location immediately above the resting area as it appears from Fig. 12.

The result presented in Fig. 13 shows that if the air change is maintained at $40 \mathrm{~m}^{3} \mathrm{pig}^{-1} \mathrm{~h}^{-1}$ then the general air temperature level will drop about three degrees. Ventilation systems in modern pig production facilities are usually designed to control the air change in a way that maintains a predefined temperature measured by a temperature sensor above the animals.

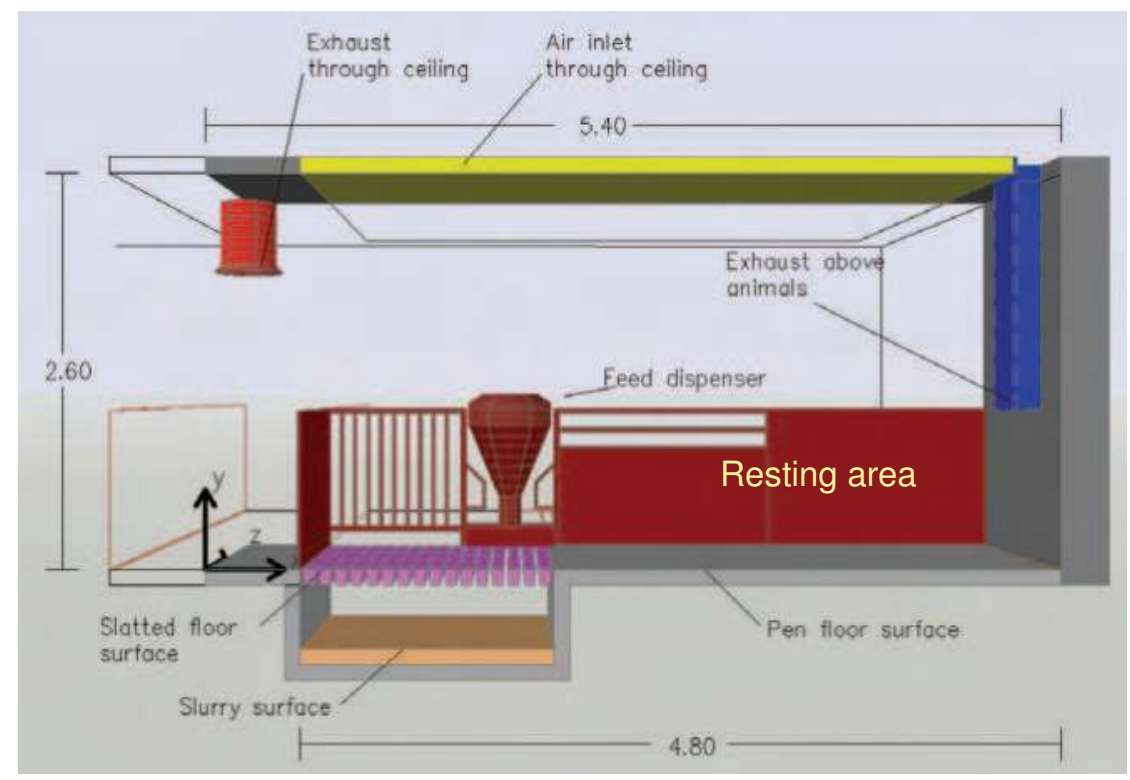

Fig. 12. Pig unit with two alternative ventilation exhausts (through ceiling or above animals). 
The lower picture in Fig. 13 shows that the air temperature distribution becomes very similar to the ceiling exhaust case if the air change is reduced $40 \%$ in the case with exhaust above the resting area. Additional analysis shows that a $40 \%$ reduction of air change in combination with location of the exhaust above the resting area will not degrade the condition in relation to carbon dioxide or ammonia concentrations in the room. Potential benefits of such an arrangement will be reduced energy consumption for running the ventilation system, reduced emissions - where especially odour emission can be expected to decrease with decreased air change and finally if air cleaning of the entire air change are required it may result in significant savings in both investments and operation cost.

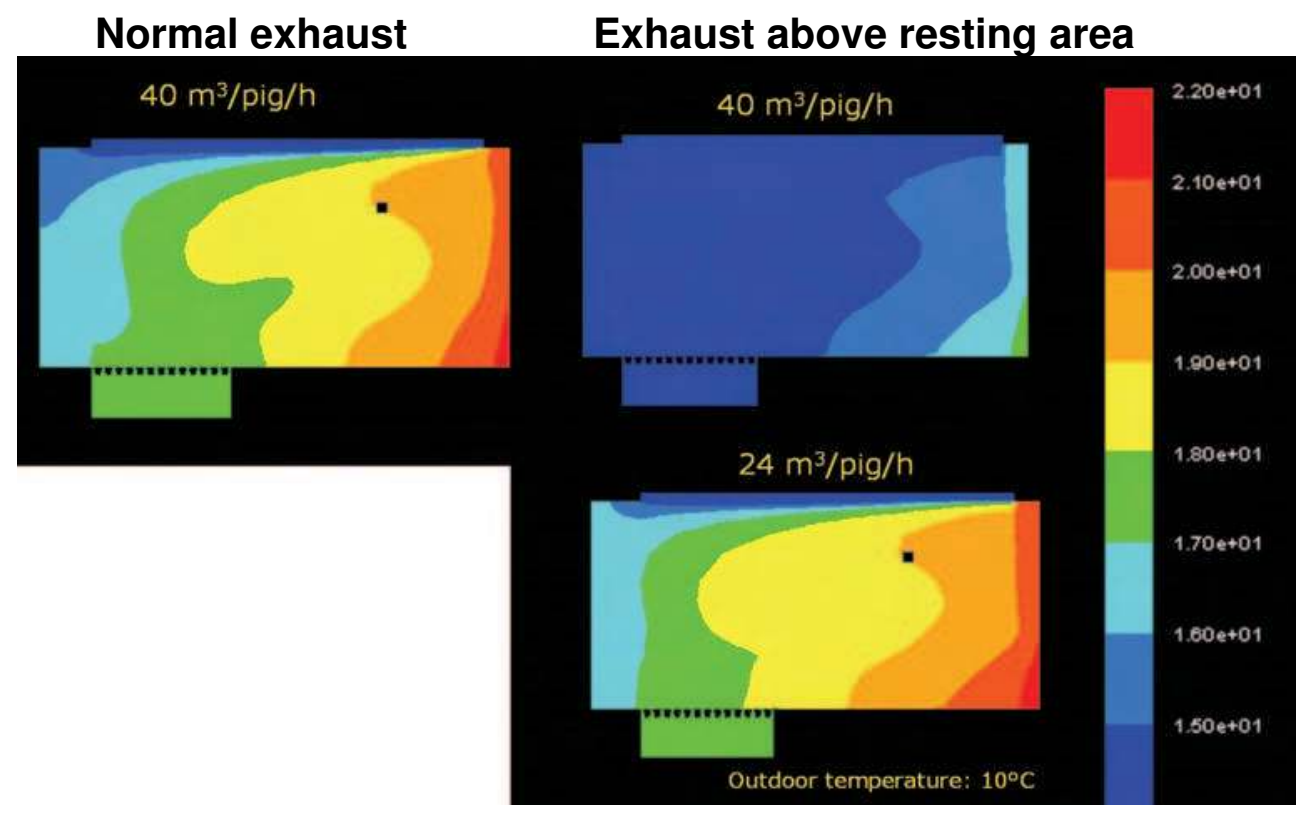

Fig. 13. CFD prediction of temperature distributions $\left({ }^{\circ} \mathrm{C}\right)$ in a pig pen at different exhaust locations and air changes.

The CFD models discussed in this chapter have until this point been delimited to the condition in one pen only, and this simplification may naturally cause that important interactions between pens will be lost. As it is indicated in Fig. 2 a normal ceiling exhaust are usually design to remove air from a number of pens. To visualize the consequences of air streams between pens Fig. 14 show results from an analysis of 3 pens corresponding to one quarter of the pig unit shown in Fig. 2. 


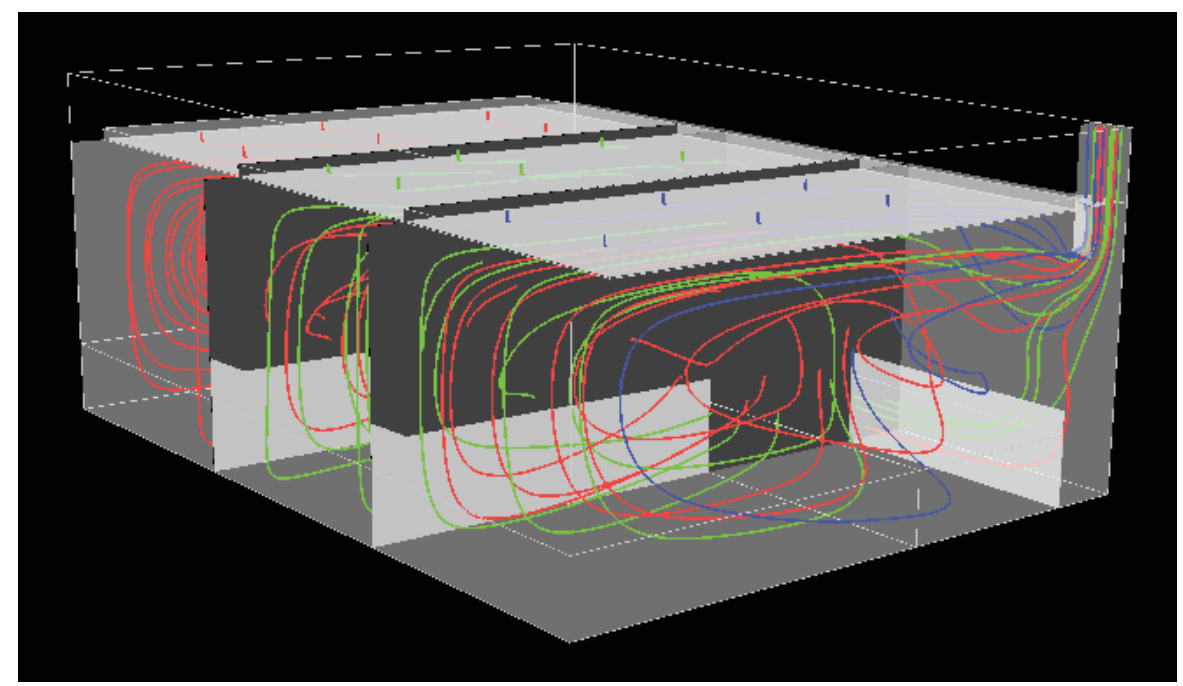

Fig. 14. Simulated air stream lines from inlet to exhaust for air entering a pig unit at 6 different locations above each of 3 pens.

The graph shows simulated stream lines for air entering the room at six locations above each pen. It appears that red stream lines entering the room above the pen in the largest distance from the exhaust pass through the animal occupied zone of al three pens, which has the negative consequence that pigs in one pen become exposed to airborne pathogens that might be released from pigs in another pen. The figure also shows that a large part of the air entering the room above the pen closet to the exhaust leaves without reaching the animal occupied zone, and as result significant difference in temperatures and concentrations between pens may occur. Subsequent analyses have shown that both problems can be avoided by installing an exhaust above the resting area in each pen.

\section{Conclusions}

The analyses, including CFD-methods (Computational Fluid Dynamics), showed that evacuating and cleaning of 10 percent of the total ventilation capacity from the pit may reduce the ammonia emission of the system with 73 percent, and the ammonia concentration in the room is significantly reduced. In a similar production system without pit ventilation cleaning of 10 percent of the ventilation capacity reduced the ammonia emission with 41 percent compared to no cleaning.

In addition analyses illustrated that CFD methods can be a very useful tool in the development of improved and more efficient ventilation systems. 


\section{References}

Anonymous (2006) Fluent 6.3 User's Guide. Fluent Inc. Fluent Inc, 10 Cavendish Court, Lebanon, NH 03766, U.S.A.

Anonymous (1999) Rockwool A-diffusrulle og Heraklith staldplade-FI Luftintag. Testreport 922 in Danish. Research Bygholm, Denmark.

Baxter S. (1984) Intensive Pig Production. Granada, London Toronto Sydney New York, 588 pp.

Bjerg, B.; Zhang, G. \& Kai, P. (2008). Porous media as boundary condition for air inlet, slatted floor and animal occupied zone in numerical simulation of air flow in a pig unit. Conference Proceedings CD paper OP-1520. AgEng2008. International Conference on Agricultural Engineering, Hersonissos, Crete, Greece, June 23-25 2008.

CIGR (1984) Report of Working Group on Climatization of Animal Houses. CIGR and the Scottish Farm Building Investigation Unit, Aberdeen, 72 pp.

Griskey, R. C. (2002). Transport Phenomena and Unit Operations. John Weley and Sons, Inc., New York. 448 pp.

Launder, B. E. \& Spalding, D. B. (1974). The numerical computation of turbulent flows. Computer Methods in Applied Mechanics and Engineering, 3, 269-289

Lyngbye, M.; Riis, A. L. \& Feilberg, A. (2006). Luftskiftets betydning for lugt- og ammoniak emission fra slagtesvinestalde. (The significance of air change on odor and ammonia emission from growing pig units) Meddelelse 756 in Danish. Danish Pig Production. 15 pp.

Melse, R. W. \& Ogink, N. W. M. (2005): Air scrubbing techniques for ammonia and odour reduction at livestock operations: Review of on-farm research in the Netherlands. Transactions of the ASAE: 48, 2303-2313.

Nielsen, P. V.; Allard, F.; Awbi.; Dawidson, L. \& Schälin, A. (2007) Computational Fluid Dynamics in Ventilation Design. Rehva Guidebook no 10. ISBN 2-9600468-9-7

Norton, T.; Sun, D.W., Grant, J.; Fallon, R. \& Dodd, V. (2007). Applications of computational fluid dynamics (CFD) in the modelling and design of ventilation systems in the agricultural industry: a review, Bioresour. Technol. 98, pp. 2386-2414.

Shih, T.-H.; Liou, W. W.; Shabbir, A. \& Zhu J. (1995) A new k-ع eddy viscosity model for high Reynolds number turbulent flows. Computer Fluids. Vol 24, No 3, pp 227-238.

Strom, J. S. \& Morsing, S. (2004). Getting started with StaldVent 5.0. Report from Danish Institute of Agricultural Sciences, Research Centre Bygholm, Horsens Denmark, 24 pp.

Sun, H.; Keener, M. K.; Deng, W.\& Michel, F. C. Jr. (2004). Development and validation of 3D CFD models to simulate airflow and ammonia distribution in a High-Rise hog building during summer and winter conditions. Agricultural Engineering International: the CIGR Journal of Scientific Research and Development. Manuscript BC 04 004. VI December, 2004.

Wagenberg, A. V.; Bjerg, B.; Bot, G. P. A. (2004). Measurements and simulation of climatic conditions in the animal occupied one in a door ventilated room for piglets. Agricultural Engineering International: The CIGR Journal of Scientific Research and Developmen, Manuscript BC 03 020, Vol VI. 
Wu B; Gebremedhin K G (2001). Numerical simulation on flow field around an animal using 3-D body-fitted coordinate system. Journal of Thermal Biology, 26, 563-573. 


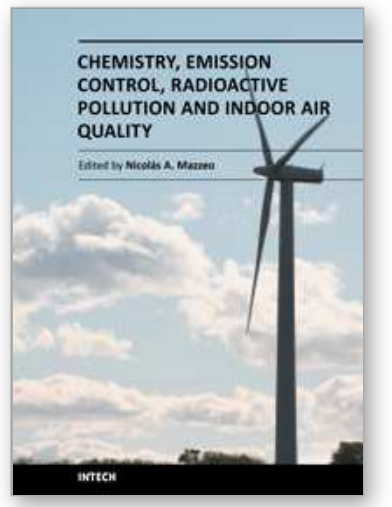

\author{
Chemistry, Emission Control, Radioactive Pollution and Indoor Air \\ Quality \\ Edited by Dr. Nicolas Mazzeo
}

ISBN 978-953-307-316-3

Hard cover, 680 pages

Publisher InTech

Published online 27, July, 2011

Published in print edition July, 2011

The atmosphere may be our most precious resource. Accordingly, the balance between its use and protection is a high priority for our civilization. While many of us would consider air pollution to be an issue that the modern world has resolved to a greater extent, it still appears to have considerable influence on the global environment. In many countries with ambitious economic growth targets the acceptable levels of air pollution have been transgressed. Serious respiratory disease related problems have been identified with both indoor and outdoor pollution throughout the world. The 25 chapters of this book deal with several air pollution issues grouped into the following sections: a) air pollution chemistry; b) air pollutant emission control; c) radioactive pollution and d) indoor air quality.

\title{
How to reference
}

In order to correctly reference this scholarly work, feel free to copy and paste the following:

Bjarne Bjerg (2011). CFD Analyses of Methods to Improve Air Quality and Efficiency of Air Cleaning in Pig Production., Chemistry, Emission Control, Radioactive Pollution and Indoor Air Quality, Dr. Nicolas Mazzeo (Ed.), ISBN: 978-953-307-316-3, InTech, Available from: http://www.intechopen.com/books/chemistryemission-control-radioactive-pollution-and-indoor-air-quality/cfd-analyses-of-methods-to-improve-air-qualityand-efficiency-of-air-cleaning-in-pig-production-

\section{INTECH}

open science | open minds

\author{
InTech Europe \\ University Campus STeP Ri \\ Slavka Krautzeka 83/A \\ 51000 Rijeka, Croatia \\ Phone: +385 (51) 770447 \\ Fax: +385 (51) 686166 \\ www.intechopen.com
}

\author{
InTech China \\ Unit 405, Office Block, Hotel Equatorial Shanghai \\ No.65, Yan An Road (West), Shanghai, 200040, China \\ 中国上海市延安西路65号上海国际贵都大饭店办公楼405单元 \\ Phone: +86-21-62489820 \\ Fax: +86-21-62489821
}


(C) 2011 The Author(s). Licensee IntechOpen. This chapter is distributed under the terms of the Creative Commons Attribution-NonCommercialShareAlike-3.0 License, which permits use, distribution and reproduction for non-commercial purposes, provided the original is properly cited and derivative works building on this content are distributed under the same license. 